\title{
Tekrarlayan Bronşioliti/Hışıltısı Olan Okul Öncesi Çocuklarda İmmünglobulin Düzeylerinin Hışıltı Fenotiplerine Göre Değerlendirilmesi
}

\author{
Evaluation of Immunoglobulin Levels According to Wheezing \\ Phenotypes in Preschool Children With Recurrent Wheezing/ \\ Bronchiolitis \\ Burcu KÖKSAL, Özlem YILMAZ ÖZBEK
}

Başkent Üniversitesi, Tıp Fakültesi, Çocuk Sağlığı ve Hastalıkları Anabilim Dalı, Çocuk Alerji Bilim Dalı, Ankara, Türkiye

\section{Öz}

Amaç: Tekrarlayan bronşiolit/hışılı okul öncesi dönemde sık görülmektedir. Epizodik hışıltı ve çoklu tetikleyici hışıltı fenotipleri tanımlanmıştır. Çalışmamızın amacı, epizodik hışıltı (EH) ve çoklu tetikleyici hışıltısı (ÇTH) olan çocukların immünglobulin düzeylerinde fark olup olmadığını belirlemektir.

Gereç ve Yöntemler: Tekrarlayan bronşiolit/hışıltısı olan 4 yaş altındaki son bir yılda en az 3 bronşiolit/hışıltı atağı geçirmiş olan çocuklar çalışmaya alındı. Hastalar fenotiplere göre epizodik ve çoklu tetikleyici hışıltı olarak iki grupta incelendi. Eozinofil sayısı, eozinofil yüzdesi, immünglobulin (lg) A, G, M düzeyleri kayıt edildi.

Bulgular: Tekrarlayan bronşioliti/hışıltısı olan 86 çocuk (55 erkek, 31 kız) çalışmaya alındı. IgA düzeyi EH (43.3ะ35 mg/ dl) Olan grupta ÇTH grubuna $(74.1 \pm 45.1 \mathrm{mg} / \mathrm{dl})$ göre daha düşük bulundu ( $p<0.001)$. IgG düzeyi de $E H$ grubunda

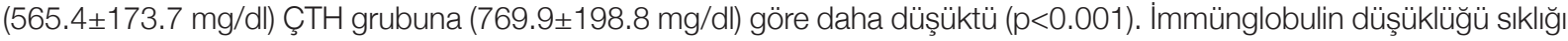
EH grubunda ( $n=12, \% 37.5)$ ÇTH grubuna $(n=4, \% 7.4)$ göre daha fazlaydı $(p<0.001)$.

Sonuç: Tekrarlayan bronşiolit/hışıltısı olan çocuklarda immünglobulin düzeylerine bakılmalı ve takip edilmelidir. Epizodik hışıltıda immünglobulin seviyelerindeki düşüklüğün de enfeksiyon sıklığını arttırarak hışıltıya yatkınlığa neden olabileceğini düşündürmektedir.

Anahtar Sözcükler: Astım, Bronşiolit, İmmünglobulinler, Fenotip, Hışıltı

\begin{abstract}
Objective: Recurrent bronchiolitis/wheeze is frequent in preschool children. Episodic viral wheeze (EVW) and mutitrigger wheezing (MTW) phenotypes have been described. Our aim was to evaluate whether immunoglobulin levels differ in children with episodic and multitrigger wheezing.
\end{abstract}

Material and Methods: Children $\leq 4$ years of age with the history of at least three episodes of acute bronchiolitis/ wheeze during the last 12 months included in study. Patients were evaluated according to wheezing phenotypes as episodic and multi-trigger wheezing. Eosinophil count, eosinophil \%, IgA, G, M levels were recorded.

Results: 86 (55 male, 31 female) children with recurrent bronchiolitits were included in study. IgA levels in EWW group $(43.3 \pm 35 \mathrm{mg} / \mathrm{dl})$ were found lower than MTW group $(74.1 \pm 45.1)(p<0.001)$. IgG levels were also lower in EWW group $(565.4 \pm 173.7 \mathrm{mg} / \mathrm{dl})$ than MTW group $(769.9 \pm 198.8 \mathrm{mg} / \mathrm{dl})(\mathrm{p}<0.0001)$. Frequency of children having low immunoglobulin levels was higher in EVW group $(n=12, \% 37.5)$ than MTW group $(n=4, \% 7.4)(p<0.001)$.

Conclusion: Immunoglobulin levels in children with recurrent bronchiolitis/wheeze should be evaluated and should be followed. We think that lower immunoglobulin levels in children with EVW may also increase infections that cause tendency to wheezing.

Key Words: Asthma, Bronchiolitis, Immunoglobulins, Phenotypes, Wheezing 


\section{GiRiş}

Okul öncesi dönemde tekrarlayan bronşiolit sık görülmektedir. Okul öncesi prevelans \%40’ bulmaktadır (1). Üç yaş altındaki çocukların yaklaşık üçte biri en az bir kez bronşiolit atağı geçirmektedir. Bronşiolitin en sık nedeni viral enfeksiyonlardır. Konjenital kalp hastalığı, bronkopulmoner displazi, reaktif hava yolu hastalığı, astım, prematürite, gastrointestinal hastalıklar, nöromuskuler hastalıklar, immun yetersizlik, kistik fibroz ve trakea özefageal fistül gibi anatomik sorunlar risk gruplarını oluşturmaktadır.

İmmünglobulin düşüklüğü olan çocuklarda sıklıkla sinüzit, otitis media, bronşiolit gibi tekrarlayan üst ve alt solunum yolu enfeksiyonları görülmektedir (2). İmmünglobulin düşüklüğü olan çocuklarda en sık başvuru nedeninin tekrarlayan bronşiolit olduğu gösterilmiștir (3). Tekrarlayan bronşioliti olan çocuklarda immünglobulinler de tam kan sayımı, akciğer grafisi ve ter testi gibi istenmesi gereken ilk tetkiklerdendir.

Okul öncesi tekrarlayan bronşioliti olan çocukların bazılarında daha sonraki yaşlarda astım gelişebilmektedir (4). Ancak hangi tekrarlayan bronşioliti olan çocuğun astım geliştireceğinin önceden tahmin edilmesi kolay olmamaktadır. Tanı ve takip kolaylığı açısından tekrarlayan hışı|tısı olan çocuklar için hışıltı fenotipleri ve astım prediktif indeksi tanımlanmıştır. Epizodik hışıltı (EH) ve çoklu tetikleyici hışıltı (ÇTH) için genetik faktörler ve atopi sorumlu tutulmaktadır. Epizodik hışıltısı olan çocuklarda sadece viral enfeksiyonlar sırasında hışıltı atağı olurken, çoklu tetikleyici hışıltısı olan çocuklarda viral enfeksiyonlar dışında da egzersiz, ağlama, sigara gibi faktörlere bağlı olarak hışılı atağı gelişmektedir (5). Epizodik hışıltısı olan çocukların çoğunda bu durum geçicidir. ÇTH'da ise okul çağında da devam edebilmektedir.

Çalışmamızın amacı tekrarlayan bronşioliti olan çocukların immünglobulin düzeylerini değerlendirmek, epizodik hışıltı ve çoklu tetikleyici hışıltısı olan çocukların immünglobulin düzeylerinde fark olup olmadığını belirlemektir.

\section{GEREÇ VE YÖNTEM}

Çalışmaya Eylül 2015- Haziran 2016 tarihleri arasında Çocuk Alerji Bölümü'ne başvuran 4 yaş altındaki ve son bir yılda en az üç bronşiolit atağı geçirmiş çocuklar alındı. Son üç ay içerisinde hışıtı atağı geçirmemişlerdi ve tekrarlayan bronşiolit dışında hastalıkları yoktu. Çalışmaya katılan çocuklar fenotiplere göre viral tetikleyici hışıltı/epizodik hışıltı ve çoklu tetikleyici hışıltı olarak iki grupta incelendi. Sadece viral enfeksiyonlar sırasında hışı|tısı olan çocuklar viral tetikleyici hışıltı grubuna (epizodik hışı|tı), viral enfeksiyon dışında da semptomu olan ve gülme, ağlama ve egzersiz ile de hışıltısı olan çocuklar çoklu tetikleyici hışıtı grubuna alındı. Kronik hastalığı olan çocuklar çalışma dışı bırakıldı.
Hastaların retrospektif olarak yaş, cinsiyet, hastalık başlama yaşı, laboratuar tetkikleri (tam kan sayımı, kanda eozinofil sayısı ve yüzdesi, CRP, IgA, G, M ve total lgE düzeyleri) kayıt edildi. Tam kan sayımı hemocytometer (Abbott Cell-Dyn Ruby system, Abbott Diagnostics, Santa Clara, CA, USA) cihazı ile, immünglobulinler türbidimetrik yöntem ile (Architect C8000, Abbott Diagnostics, Santa Clara, CA, USA) ve CRP (Alinity CC, Abbott Diagnostics, Santa Clara, CA, USA) turbidimetrik yöntem ile çalışılmıştı.

İmmünglobulin düzeylerinin yaşa göre olması gereken sınırları değerlendirilerek lg düzeylerinde düşüklük olup olmadığı belirlendi (6). IgA, M ve G değerleri 2 standart sapma altında ise düşük kabul edildi (6).

Hastalar ayrıca astım prediktif indeks (API) pozitifliğine göre değerlendirildi (7). Modifiye API (mAPI) kullanıldı. Bir majör veya iki minör kriter pozitif ise mAPI pozitif kabul edildi. Major mAPI kriterleri; ebeveynde astım, çocukta doktor tanılı atopik egzema, aeroalerjen duyarlıı̆ı olması, minor mAPI kriterleri ise soğuk algınlığı olmadan hışıltı, periferik eozinofili ( $\geq \% 4)$ ve besin alerjen duyarıı̆ı̆ı olmasını içermektedir (8). Çalışma Başkent Üniversitesi Etik Kurulu tarafından onaylandı (KA18/227).

\section{İstatistiksel analiz}

İstatistiksel analiz için SPSS 18 kullanıldı. Değişkenlerin normal dağılıma uygunluğu görsel (histogram ve olasılık grafikleri) ve analitik yöntemlerle (Kolmogorov-Smirnov/ShapiroWilks) incelendi. Tanımlayıcı analizler normal dağılan değişkenler için ortalama ve standart sapma kullanıldı. Normal dağılan sayısal değişkenlerin karşılaştırılmasında ikili gruplarda student t-test, normal dağılmayan sayısal değişkenlerin karşılaştııılmasında ikili gruplarda Mann-Whitney $U$ test kullanıldı. Oran karşılaştırmasında ise Kikare testleri kullanıldı. p değerinin $<0.05$ olması anlamlı kabul edildi.

\section{BULGULAR}

Tekrarlayan bronşioliti olan 4 yaş altındaki son bir yılda en az 3 bronşiolit atağı geçirmiș olan 86 çocuk çalıșmaya alındı. Çocukların 32'sinde (\%37.2) EH ve 54'ünde (\%62.8) ÇTH vardı. Çalışmaya katılan çocukların özellikleri Tablo I'de verilmiştir.

Tekrarlayan bronşioliti olan çocukların Ig düzeyleri yaşa göre değerlendirildiğinde düşüklük saptanan 16 vaka (\%18.6) vardı.

Hastalar immünglobulin düzeylerine göre karşılaştıııldığında IgA düzeyi EH $(43.3 \pm 35 \mathrm{mg} / \mathrm{dl})$ olan grupta ÇTH grubuna $(74.1 \pm 45.1 \mathrm{mg} / \mathrm{dl})$ göre daha düşük bulundu ( $p<0.001)$ (Şekil 1). IgG düzeyi de EH grubunda (565.4 173.7 mg/dl) ÇTH grubuna

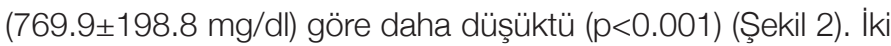
grup arasında lgE düzeyleri karşılaştırıldığında fark yoktu. EH olan çocukların IgM düzeyi $(86.8 \pm 38.2 \mathrm{mg} / \mathrm{dl})$ ÇTH grubuna

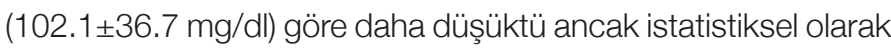
anlamlı fark görülmedi ( $p=0.07)$ (Tablo II). 
Tablo I. Tekrarlayan bronşioliti olan çocukların hışılı fenotiplerine göre demografik özellikleri.

\begin{tabular}{|c|c|c|c|}
\hline & Epizodik Hışıltı & Çoklu Tetikleyici Hışıltı & \\
\hline $\mathbf{n}$ & 32 & 54 & $\mathbf{p}$ \\
\hline $\mathrm{E} / \mathrm{K}$ & $20 / 12$ & $35 / 19$ & 0.010 \\
\hline Yaş(yıl) & $\begin{array}{c}2.2 \pm 0.9 \\
1-4\end{array}$ & $\begin{array}{c}2.6 \pm 0.9 \\
1-4\end{array}$ & 0.001 \\
\hline Hastalık süresi (ay) ${ }^{*}$ & $\begin{array}{c}19.2 \pm 10.1 \\
3-36\end{array}$ & $\begin{array}{c}16.8 \pm 9.2 \\
3-42\end{array}$ & 0.032 \\
\hline İlk bronşiolit (ay) ${ }^{*}$ & $\begin{array}{c}8.5 \pm 5.5 \\
2-24\end{array}$ & $\begin{array}{c}15.4 \pm 9.5 \\
2-36\end{array}$ & $<0.001$ \\
\hline Atak sayı/yıl ${ }^{*}$ & $\begin{array}{c}4.7 \pm 1.3 \\
3-8\end{array}$ & $\begin{array}{c}4.7 \pm 1.4 \\
3-10\end{array}$ & 0.089 \\
\hline Atopik dermatit & 8 & 4 & 0.002 \\
\hline Besin alerjisi & 2 & 4 & \\
\hline Deri prik testi & 6 & 34 & $<0.001$ \\
\hline Atopi & 5 & 36 & $<0.01$ \\
\hline Sigara & 1 & 6 & 0.023 \\
\hline Evde hayvan & 3 & 6 & 0.072 \\
\hline Ailede alerji & 19 & 32 & 0.081 \\
\hline Ailede astım & 10 & 15 & 0.037 \\
\hline API pozitif & 12 & 36 & 0.004 \\
\hline
\end{tabular}

API:Astım prediktif indeks; Sonuçlar n değerleri veya *ortalama $\$ S D$, min-max olarak ifade edilmiştir.

Tablo II. Tekrarlayan bronşioliti olan çocukların hışıltı fenotiplerine göre laboratuar bulguları.

\begin{tabular}{|c|c|c|c|}
\hline & Epizodik Hışıltı & Çoklu Tetikleyici Hışıltı & $\mathbf{p}$ \\
\hline $\lg A(m g / d L)$ & $\begin{array}{c}43.3 \pm 35 \\
8-173\end{array}$ & $\begin{array}{c}74.1 \pm 45.1 \\
29-223\end{array}$ & $<0.001$ \\
\hline $\lg M(m g / d L)$ & $\begin{array}{c}86.8 \pm 38.2 \\
31-212\end{array}$ & $\begin{array}{c}102.1 \pm 36.7 \\
35-211\end{array}$ & 0.007 \\
\hline IgG (mg/dL) & $\begin{array}{c}565.4 \pm 173.7 \\
228-922\end{array}$ & $\begin{array}{c}769.9 \pm 198.8 \\
299-1307\end{array}$ & $<0.001$ \\
\hline $\operatorname{lgE}(I U / m l)$ & $\begin{array}{c}44.2 \pm 69.1 \\
1.4-284\end{array}$ & $\begin{array}{c}79.5 \pm 118.4 \\
1.1-675\end{array}$ & 0.014 \\
\hline $\mathrm{Hb}(\mathrm{g} / \mathrm{dL})$ & $\begin{array}{l}12 \pm 1.3 \\
10-15.6\end{array}$ & $\begin{array}{c}12 \pm 0.9 \\
10-14\end{array}$ & 0.099 \\
\hline 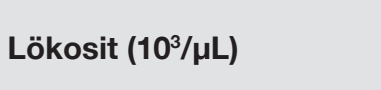 & $\begin{array}{l}9200 \pm 2772 \\
6500-14000\end{array}$ & $\begin{array}{l}9137 \pm 2725 \\
4450-15000\end{array}$ & 0.092 \\
\hline Total eozinofil $\left(10^{3} / \mu \mathrm{L}\right)$ & $\begin{array}{c}272.2 \pm 174.7 \\
16-613\end{array}$ & $\begin{array}{c}260.1 \pm 221.7 \\
18-945\end{array}$ & 0.081 \\
\hline Eozinofil (\%) & $\begin{array}{c}2.9 \pm 1.6 \\
0.2-6\end{array}$ & $\begin{array}{c}2.8 \pm 2.2 \\
0.2-11\end{array}$ & 0.084 \\
\hline Trombosit sayısı $\left(10^{3} / \mu L\right)$ & $\begin{array}{c}328153.8 \pm 76624.6 \\
145000-461000\end{array}$ & $\begin{array}{c}355577.8 \pm 116229.3 \\
184000-647000\end{array}$ & 0.029 \\
\hline CRP (mg/L) & $\begin{array}{c}3.3 \pm 4.9 \\
0.1-16\end{array}$ & $\begin{array}{c}3.8 \pm 6.5 \\
0.1-32\end{array}$ & 0.075 \\
\hline
\end{tabular}

Sonuçlar ortalama $\pm S D$, min-max olarak ifade edilmiştir. 


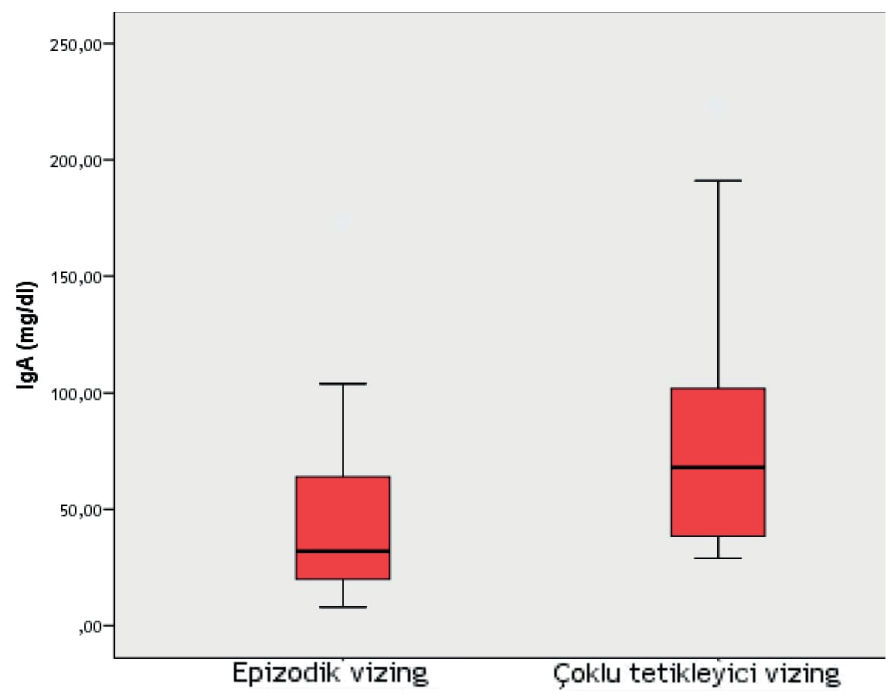

Şekil 1. IgA düzeylerinin hışıltı fenotiplerine göre karşılaştırılması

İmmünglobulin düşüklüğü sıklı̆ı EH grubunda ( $n=12, \% 37.5)$ ÇTH grubuna ( $n=4, \% 7.4)$ göre daha fazlaydı $(p<0.001)$. EH grubunda lgA düşüklüğü olan 4, IgG düşüklüğü olan 11 ve lgM düşüklüğü olan 4 hasta vardı. ÇTH grubunda ise IgG düşüklüğü olan 3, IgM düşüklüğü olan 1 hasta vardı ve IgA düşüklüğü olan hasta yoktu.

Epizodik hışıttılı çocukların $(8.5 \pm 5.5$ ay) ilk bronşiolit yaşı ÇTH grubuna $(15.4 \pm 9.5$ ay) göre daha düşük bulundu $(p<0.01)$ (Tablo I).

Yaşa göre immünglobulin düşüklüğü olan çocuklar gruplardan çıkarılıp tekrar değerlendirildiğinde EH grubundaki çocukların lgG düzeyleri $(655.5 \pm 128.5 \mathrm{mg} / \mathrm{dl}) \quad$ ÇTH grubundakilere $(799.4 \pm 173.1 \mathrm{mg} / \mathrm{dl})$ göre daha düşüktü $(p<0.001)$. IgA düzeyleri karşılaştırıldığında ise EH ve ÇTH grupları arasında fark yoktu $(57.8 \pm 36.8 \mathrm{mg} / \mathrm{dl}$ vs. $75 \pm 46.1 \mathrm{mg} / \mathrm{dll})$.

Onbir (\%12.7) çocukta atopik dermatit hikayesi vardı. 6 (\%6.9) çocukta besin alerjisi vardı.

Hastalar mAPI pozitifliğine göre karşılaştııılığında API pozitif $(n=48)$ ve API negatif ( $n=38$ ) olan gruplar arasinda IgA, $G, M$ ve total IgE düzeyleri açısından fark görülmedi.

\section{TARTIŞMA}

Astım, çocukluk çağında en sık görülen kronik hastalıklardan biridir. Son yıllarda astım sıklığı artmıştır. Astımı olan çocukların çoğunun hayatlarının ilkyıllarında semptomlar ortaya çıkmaktadır. Ancak astım tanısını koymak okul öncesi çocuklarda zordur. Öncelikle diğer nedenlerin dışlanması gerekmektedir. Okul öncesi yaş grubunda astımın ilk bulguları çoğunlukla tekrarlayan bronşiolit/hışıltı olarak karşımıza çıkmaktadır. Diğer taraftan her tekrarlayan hıșilısı olan çocuk astım değildir (9). Tekrarlayan bronşioliti/hışıtısı olan çocukların hangilerinin astım olacağını

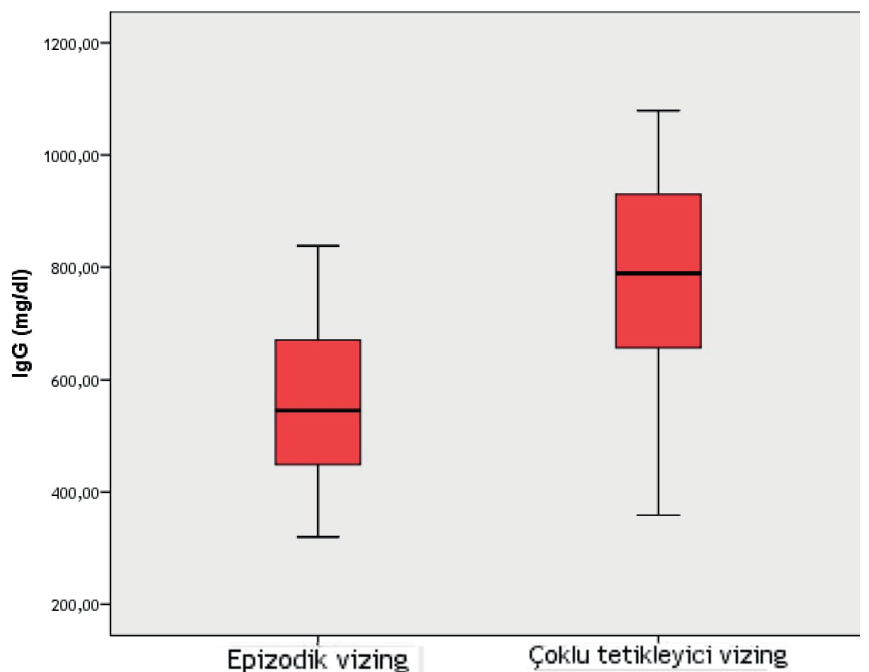

Şekil 2. IgG düzeylerinin hışıltı fenotiplerine göre karşılaştıııması

tahmin etmek klinisyenler için kolay olmamaktadır. Bu çocukların tanılarının konulması, takip ve tedavilerinin belirlenebilmesi için hangi çocuğun astım hangisinin astım olmadığının ayırt edilmesi önem taşımaktadır $(10,11)$. Bu nedenle okul öncesi çocuklarda astım için risk faktörleri ve hışltıya yatkınlığın nedenlerinin araştııılı̆ğı çalışmalar ilgi çekmektedir $(12,13)$.

Çocukların bazılarında sadece viral enfeksiyonlarla hıșltı olurken, bazılarında viral enfeksiyonlara ek olarak alerjen, sigara, parfüm ve egzersiz gibi etkenlerle hışıltı atakları olabilmektedir $(14,15)$. Bu farkllık için birçok hastalıkta olduğu gibi ilk başta genetik faktörler sorumlu tutulmaktadır (16). Ancak genetik faktörlerin hangi mekanizmalarla bu farkllıklara neden olduğu araştırma konusudur ve birçok çalışma ile altta yatabilecek nedenler aydınlatılımaya çalıșılmaktadır $(3,4,17)$. Viral enfeksiyon sırasında bronşlarda aşırı cevap sonucu hışıltı oluşması genetik faktörlerle açıklanabilmektedir. Bu iki grubun viral enfeksiyonlar sırasında da sitokin cevaplarının farklı olduğu düşünülmektedir $(18,19)$. Ancak genetik faktörlerin neden olduğu farklı mekanizmalar da olabilir. Epizodik hıșitısı olan çocuklarda sadece viral enfeksiyon ile hıșiltı olurken, çoklu tetikleyici hıșiltısı olan çocuklarda olduğu gibi diğer etkenlerle karşılaşıldığında da hışılı olması immün cevaptaki farkllıklar ile açıklanabilir. Biz de çalışmamızda sadece viral enfeksiyonlarla hışıltısı olan çocukların çoklu tetikleyici hışılııı olan çocuklara göre lgA ve lgG düzeylerinin daha düşük olduğunu saptadık. Bu sonuç da viral enfeksiyonlar sırasında tekrarlayan hışıltıya yatkınlığı açıklayacak nedenlerden biri olabilir. Tekrarlayan hış|tısı olan çocuklarda fenotiplere göre immünglobulin düzeylerinin karşılaştırılığı bir çalısmaya literatürde rastlanmamıştır. Çalışmamızda sadece viral enfeksiyonlarla hışılı atakları olan çocukların IgA ve IgG değerlerinin çoklu tetikleyici hışıtııı çocuklara göre daha düşük olmasıyla birlikte immünglobulin düşüklüğü sıklığının $\mathrm{EH}$ grubunda ÇTH grubuna göre daha fazla olduğu da saptandı. 
Bu sonuçlar epizodik hışıltısı olan çocuklarda hışıltıya yatkınlığın gelişmesinde immünglobulinlerin de önemli olabileceğini göstermektedir. Ayrıca çalışmamızda epizodik hışıltıı çocukların ilk bronşiolit yaşının ÇTH çocuklara göre daha düşük olduğu bulunmuştur. Çalışmamızla uyumlu olarak bazı yayınlarda da benzer sonuçlar olduğu tespit edilmiştir $(20,21)$.

Hışıltıların büyük çoğunluğu viral enfeksiyonlar sırasında gelişmektedir $(22,23)$. ÇTH olan çocuklarda viral enfeksiyon dışında da hışıltı ataklarıın olması genetik, bronşial aşıı duyarlıık ve atopi gibi başka faktörlerin rol aldığını desteklemektedir. ÇTH'lı çocuklarda bronşlarda süregelen inflamasyon olduğu veya inflamasyon daha şiddetli olduğu için hava yollarının daha duyarlı olması nedeniyle hava kirliliği, soğuk hava, sigara gibi çevresel faktörler, egzersiz, gülme, alerjen, iritan gibi faktörlerle de hışıltı oluşmaktadır.

Epizodik hışıltısı olan çocuklarda sadece viral enfeksiyonlarla tetiklenen vizing görülmektedir ve büyük çoğunluğunda yaşla birlikte şikayetler azalmaktadır veya geçmektedir. Epizodik hışıltı grubunda ÇTH grubuna göre Ig A ve lg $G$ değerlerinin daha düşük olması ve epizodik hışıltısı olan çocukların daha erken yaşlarda bronşiolit ataklarının başlaması, bu gruptaki çocuklarda immünglobulin düşüklüğüne bağlı olarak daha erken yaşlarda bronşiolit ataklarıın başlamış olabileceğini ve sadece enfeksiyonlarla bronşiolitin/hışılının tetiklendiğini düşündürmüştür.

Epizodik hışıltı sıkığı genelde yaş büyüdükçe azalmaktadır. Immünglobulin seviyeleri düşük olan çocuklarda yaşla birlikte immünglobulin seviyelerinin artmasılyla da enfeksiyon riskinin ve hışı|tı sıklı̆ı̆ının azalmasına katkıda bulunduğu düşünülmüştür. ÇTH'da ise farklı genetik faktörler etkili olduğundan yaş büyüse de viral enfeksiyonlarla hışıltı devam edebilmektedir. EH için genetik faktörlerin yanında immünglobulin düşüklüğünün de hışıltıya olan yatkınlığa katkıda bulunduğu ancak ÇTH için bu durumun söz konusu olmadığı söylenebilir.

Tekrarlayan bronşioliti olan çocuklarda akciğer grafisi, tam kan sayımı, total lenfosit, total nötrofil sayısı, IgA, IgG, IgM düzeyleri ve ter testi yapılması gereken bazal tetkiklerdir. Altta yatabilecek gastroözafageal reflü, kistik fibroz, kalp hastalığı ve diğer konjenital hastallklar hikaye, fizik muayene ve/veya yapilacak tetkiklerle ekarte edildikten sonra hastalar takibe alınmalıdır.

Tekrarlayan bronșioliti olan çocukların bir kısmında astım gelişebilmektedir. Okul öncesi dönemde hangi çocuklarda astım gelişeceğinin belirlenmesi güç olmaktadır. Astım prediktif indeks pozitifliğinin olması da çocukluk çağı astımının tahmininde yardımcı olmaktadır. Çalışmamızda, astım prediktif indeksi pozitif olan çocukların immünglobulin düzeyleri ile negatif olanlar arasında fark bulunamamıștı. Bu sonuç, immünglobulin düzeylerinin astım gelişimini öngörmede faydalı olmadığını gösterebilir.

Atopi varlığı, immün cevaptaki farklılıklar, hava yolu fonksiyonu ve çocuklukçağı astımı arasındaki ilişkiler oldukça karmaşık olmakla birlikte henüz tam olarak açıklanamamaktadır. Tekrarlayan hışı|ısı olan çocuklarda fenotiplere göre immünglobulin düzeylerinin de farklı olduğu görülmüştür. Özellikle EH'lı çocuklarda genetik olarak enfeksiyon sırasında hışıtıya yatkınlık olsa da düşük immünglobulin değerlerinin de bu duruma katkıda bulunduğunu desteklemektedir. İmmünglobulinler yükselmeye ve bağışıklık sistemi olgunlaşmaya başladıkça hışılı sıklı̆ının azalması beklenen bir sonuçtur.

Sonuç olarak, viral enfeksiyonlarla tetiklenen hışılısı olan çocukların immünglobulin $A$ ve $G$ düzeylerinin ÇTH'ı çocuklara göre daha düșük bulunması EH fenotipine sahip çocukların hışıltıya yatkınlığını açıklayabilecek faktörlerden biri olduğunu gösterebilir. Tekrarlayan bronşioliti olan çocuklarda immünglobulin düzeylerine bakılmalı ve takip edilmelidir.

\section{Finansal Kaynak}

Bu çalışma sırasında, yapılan araştırma konusu ile ilgili doğrudan bağlantısı bulunan herhangi bir ilaç firmasından, tıbbi alet, gereç ve malzeme sağlayan ve/veya üreten bir firma veya herhangi bir ticari firmadan, çalışmanın değerlendirme sürecinde, çalıșma ile ilgili verilecek kararı olumsuz etkileyebilecek maddi ve/veya manevi herhangi bir destek alınmamıştır.

\section{Çıkar Çatışması}

Bu çalsşma ile ilgili olarak yazarların ve/veya aile bireylerinin çıkar çatışması potansiyeli olabilecek bilimsel ve tıbbi komite üyeliği veya üyeleri ile ilişkisi, danışmanlık, bilirkişilik, herhangi bir firmada çalışma durumu, hissedarlık ve benzer durumları yoktur.

\section{KAYNAKLAR}

1. Martinez FD, Wright AL, Taussig LM, Holberg CJ, Halonen M, Morgan WJ. Asthma and wheezing in the first six years of life. The Group Health Medical Associates. N Engl J Med 1995;332:133-8.

2. Whelan MA, Hwan WH, Beausoleil J, Hauck WW, McGeady SJ. Infants presenting with recurrent infections and low immunoglobulins: characteristics and analysis of normalization. J Clin Immunol 2006;26:7-11.

3. Kocacık Uygun DF, Filiz S, Yeğin O. Süt çocukluğunun geçici hipogamaglobulinemi ön tanılı olgularımızın değerlendirilmesi. J Pediatr Res 2015;2:128-33.

4. Taussing LM, Wright AL, Holberg CJ, Halonen M, Morgan WS, Martinez FD, et al. Tuscon Children's Respiratory Study: 1980 to present. J Allergy Clin Immunol 2003; 111:661-75.

5. Brand $\mathrm{PL}$, Baraldi $\mathrm{E}$, Bisgaard $\mathrm{H}$, Boner AL, Castro-Rodriguez JA, Custovic A, et al. Definition, assessment and treatment of wheezing. Eur Respir J 2008;32:1096-110.

6. Tezcan I, Berkel Al, Ersoy F, Sanal O. Serum immunoglobulin levels with turbidimetric method in healthy Turkish children and adults. Turkish J Pediatr Dis 1996;39:649-56.

7. Castro-Rodriguez JA. The Asthma Predictive Index: A very useful tool for predicting asthma in young children. J Allergy Clin Immunol 2010;126:212-6.

8. Guilbert TW, Morgan WJ, Krawiec M, Lemanske RF. The Prevention of Early Asthma in Kids study: design, rationale and methods for the Childhood Asthma Research and Education network. Control Clin Trials 2004;25:286-310. 
9. Morgan WJ, Stern DA, Sherrill DL, Guerra S, Holberg CJ, Guilbert TW, et al. Outcome of asthma and wheezing in the first 6 years of life: follow-up through adolescence. Am J Respir Crit Care Med 2005;172:1253-8.

10. Savenije OE, Kerkhof M, Koppelman GH, Postma DS. Predicting who will have asthma at school age among preschool children. $J$ Allergy Clin Immunol 2012;130:325-31.

11. Castro-Rodríguez JA, Rodrigo GJ. Efficacy of inhaled corticosteroids in infants and preschoolers with recurrent wheezing and asthma: a systematic review with meta-analysis. Pediatrics 2009;123:e519-25.

12. Määttä $A M$, Kotaniemi-Syrjänen $A$, Malmström $K$, Malmberg LP, Sundvall J, Pelkonen AS, et al. Vitamin D, high-sensitivity C-reactive protein, and airway hyperresponsiveness in infants with recurrent respiratory symptoms. Ann Allergy Asthma Immunol 2017;119:227-31.

13. Kawamoto N, Fukao T, Kaneko H, Hirayama K, Sakurai S, Arai $\mathrm{T}$, et al. Risk factors for infantile atopic dermatitis and recurrent wheezing. J Investig Allergol Clin Immunol 2012;22:116-25.

14. Hansbro NG, Horvat JC, Wark PA, Hansbro PM. Understanding the mechanisms of viral induced asthma: new therapeutic directions. Pharmacol Ther 2008;117:313-53.

15. Lemanske RF Jr, Jackson DJ, Gangnon RE, Evans MD, Li Z, Shult PA, et al. Rhinovirus illnesses during infancy predict subsequent childhood wheezing. J Allergy Clin Immunol 2005;116:571-7.

16. Nwokoro C, Grigg J. Preschool wheeze, genes and treatment. Paediatr Respir Rev 2018;28:47-54.
17. Yao W, Barbe-Tuana FM, Llapur CJ, Jones MH, Tiller C, Kimmel $\mathrm{R}$, et al. Evaluation of airway reactivity and immune characteristics as risk factors for wheezing early in life. J Allergy Clin Immunol 2010;126:483-8.

18. Sarria EE, Mattiello R, Yao W, Chakr V, Tiller CJ, Kisling J. Atopy, cytokine production, and airway reactivity as predictors of preschool asthma and airway responsiveness. Pediatr Pulmonol 2014;49:132-9

19. Rothers J, Halonen M, Stern DA, Lohman IC, Mobley S, Spangenberg A, et al. Adaptive cytokine production in early life differentially predicts total IgE levels and asthma through age 5 years. J Allergy Clin Immunol 2011;128:397-402.

20. İnal A, Kendirli SG, Altıntaş DU, Yılmaz M, Karakoç GB. Hışıltılı çocuklarda etiyoloji: dört yıllık verilerimiz. Türkiye Çocuk Hast Derg 2009;3:24-30.

21. Topal E, Bakırtaş A, Yılmaz Ö, Ertoy Karagöl IH, Arga M, Demirsoy MS, et al. Okul öncesi yaș grubunda iki ana hıșıltı fenotipi: Benzerlikleri, farklılıkları ve klinik seyirlerinin karşılaştıııması. Asthma Allergy Immunol 2012;10:121-8.

22. Jackson DJ, Gangnon RE, Evans MD, Roberg KA, Anderson EL, Pappas TE, et al. Wheezing rhinovirus illnesses in early life predict asthma development in high-risk children. Am J Respir Crit Care Med 2008;178:667-72.

23. Kusel MM, de Klerk NH, Kebadze T, Vohma V, Holt PG, Johnston $S L$, et al. Early-life respiratory viral infections, atopic sensitization, and risk of subsequent development of persistent asthma. J Allergy Clin Immunol 2007;119:1105-10. 